\title{
Faktor-Faktor yang Mempengaruhi Pernjualan Mobil Sedan di Indonesia dan Memprediksi Penerimaan Pajak Penjualan atas Barang Mewah (PPnBM) Kendaraan Mobil Periode 2013-2017
}

\author{
Audrey Alviona Ribuna Kaban ${ }^{1}$; Sri Yani Kusumastuti ${ }^{1 *}$
}

\section{INFO ARTIKEL}

\begin{tabular}{l} 
Penulis: \\
${ }^{1}$ Fakultas Ekonomi dan Bisnis, \\
Universitas Trisakti, Jakarta, \\
Indonesia \\
${ }^{*}$ E-mail: sriyani.k@trisakti.ac.id \\
\hline
\end{tabular}

Untuk mengutip artikel ini:

Kaban AAR \& Kusumastuti SY 2019, 'Faktor-faktor yang mempe ngaruhi pernjualan mobil sedan di indonesia dan memprediksi peneri maan pajak penjualan atas barang mewah (ppnbm) kendaraan mobil periode 2013-2017', Jurnal Ekonomi KIAT, vol. 30, no. 1, hal. 44-53.

\section{Akses online:}

www.jurnalkiatuir.com

E-mail:

kiat@journal.uir.ac.id

\begin{abstract}
AbStraK
This study aims to examine the effect of previously sales, price of the goods, and price of subtitute goods to sales of sedan car. Independent variables used in this study previously sales, price of the goods, and price of subtitute goods, and prediction of sales tax on luxury goods. Shile the dependent variable in thisstudy was measured using sales of sedan cars the measured of the car unit is succesfully sold every year during in the period 2013-2017. The population in this study amounted to 24 sedan's companies list on Combined Motor Vehicle Industry (GAIKINDO) during 2013 until 2017. Determination of the sample using purpossive sampling method and obtained a sample of 5 sedan's companies based on certain criteria. The analysis tool used in the panel and the selected model is fixed effect model. The result show that previous sales has positively effect on the sales of sedan car, price of the goods has positive effect on the sales of sedan car. Meanwhile price of subtitute goods has negative effect on the sales of sedan car.
\end{abstract}

Katakunci: Sedan Car Sales, Previously Sales, Price of The Goods, Price of Substitute Goods, and Prediction of Sales Tax on Luxury Goods

\section{Di bawah lisensi: \\ Creative Commons Attribute- \\ ShareAlike $4.0 \quad$ International \\ Licence}

\section{Pendahuluan}

Angka penjualan kendaraan bermotor kategori sedan yang dicatat oleh Gaikindo (Gabungan Indstri Kendaran Bermotor) mengalamin penurunan. Pada tahun 2017, penjualan mobil sedan mencapai sekitar 9 ribu unit, turun 34\% dari tahun 2016 yang mencapai sekitar 13 ribu unit. Salah satu faktor yang diduga menjadi turunnya penjualan sedan adalah harga, di mana Harga Pokok Penjualan (HPP) mobil sedan yang sudah mahal ditambah lagi tarif PPnBM nya sebesar $30 \%$ hingga $40 \%$ dan menipisnya pasokan produksi di dalam negeri yang dikarenakan penjualan mobil sedan menurun anjlok yang membuat produsen enggan untuk memproduksinya, sebab harga mobil sedan dilihat dari HPP dan tarif
PPnBMnya lebih tinggi dibanding jenis mobil lainnya yang hanya memiliki HPP lebih murah dan tarif PPnBM hanya 10\% hingga $20 \%$, sehingga para produsen mobil lebih memilih untuk memproduksi mobil jenis 4x2 atau MPV (Multi Purpose Vehicle), (Finance Detik.com, 2017). Oleh karena itu, perusahaan saat ini sedang mengajukan usulan ke pemerintah untuk menyetarakan tarif PPnBM kendaraan mobil. Dengan turunnya tarif PPnBM sedan, ada harapan penjualan sedan menjadi meningkat dibanding sebelumnya, sebab pada dasarnya minat masyarakat terhadap mobil sedan masih cukup tinggi asalkan harganya lebih murah. Berikut data penjualan dan harga rata-rata mobil Sedan dan MPV selama 5 tahun terakhir dari tahun 2013 s/d 2017.

Tabel 1. Jumlah penjualan dan rata-rata harga mobil sedan dan MPV di Indonesia

\begin{tabular}{ccccc}
\hline Tahun & $\begin{array}{c}\text { Penjualan Sedan } \\
\text { (unit) }\end{array}$ & $\begin{array}{c}\text { Rata-Rata Harga } \\
\text { Sedan (Rp) }\end{array}$ & $\begin{array}{c}\text { Penjualan MPV } \\
\text { (unit) }\end{array}$ & $\begin{array}{c}\text { Rata-Rata Harga } \\
\text { MPV (Rp) }\end{array}$ \\
\hline 2013 & 34.193 & 627.738 .000 & 541.045 & 244.184 .000 \\
2014 & 21.184 & 678.708 .000 & 473.586 & 243.304 .000 \\
2015 & 17.422 & 641.270 .000 & 343.322 & 277.482 .000 \\
2016 & 13.382 & 670.541 .000 & 354.505 & 304.850 .000 \\
2017 & 9.139 & 809.162 .000 & 358.521 & 301.358 .000 \\
\hline
\end{tabular}


Sumber: www.gaikindo.or.id (2019)

Data Tabel 1, menunjukkan bahwa memang terjadi penurunan penjualan mobil sedan yang cukup anjlok dari tahun 2013 s/d 2017 dikarenakan harga dan tarif PPnBM sedan yang tinggi, jika penjualan sedan selalu mengalami penurunan yang drastis maka akan berdampak pada penerimaan PPnBM di mana semakin berkurang penerimaan PPnBM maka akan semakin kecil pendapatan negara. Berikut, data prediksi penerimaan PPnBM seluruh kendaraan mobil sedan dan mobil MPV dengan tarif masingmasing selama 5 tahun terakhir sejak 2013 s/d 2017.

Data Tabel 2, menunjukkan bahwa penerimaan PPnBM mobil sedan selama 5 tahun menurun drastis dari angka Rp4.953 Milyar menjadi Rp 1.706 Milyar. Turunnya penerimaan PPnBM mobil sedan dikarenakan penjualannya yang menurun juga, berbeda dengan penerimaan PPnBM mobil MPV yang angkanya lebih besar dan stabil dari Rp 12.010 Milyar menjadi Rp 9.816 Milyar. Dilihat dari total penerimaan PPnBM nya menunjukkan bahwa penerimaan PPnBM mobil sedan tiga kali lipat lebih kecil daripada penerimaan PPnBM mobil MPV, sehingga adanya permasalahan pada penghasilan negara jika penjualan sedan akan terus menurun pada periode berikutnya.

Tabel 2. Total penerimaan PPnBM mobil sedan dan MPV di Indonesia

\begin{tabular}{lcccc}
\hline Tahun & $\begin{array}{c}\text { Tarif PPnBM } \\
\text { Sedan (\%) }\end{array}$ & $\begin{array}{c}\text { Tarif PPnBM } \\
\text { MPV (\%) }\end{array}$ & $\begin{array}{c}\text { Penerimaan PPnBM } \\
\text { Sedan (Milyar Rp) }\end{array}$ & $\begin{array}{c}\text { Penerimaan PPnBM } \\
\text { MPV (Milyar Rp) }\end{array}$ \\
\hline 2013 & 30 & 10 & 4.953 & 12.010 \\
2014 & 30 & 10 & 3.318 & 10.475 \\
2015 & 30 & 10 & 2.578 & 8.660 \\
2016 & 30 & 10 & 2.071 & 9.824 \\
2017 & 30 & 10 & 1.706 & 9.816 \\
\hline Total Penerimaan PPnBM & & $\mathbf{1 4 . 6 2 6}$ & $\mathbf{5 0 . 7 8 5}$ \\
\hline
\end{tabular}

Sumber: katadata.co.id (2019)

Menurunnya penjualan mobil yang drastis bisa disebabkan karena penjualan dimasa lalu, hal itu sesuai dengan teori ekonomi yaitu teori inersia yang menyatakan bahwa kejadian saat ini dipengaruhi oleh kejadian sebelumnya. Faktor lainnya adalah harga barang itu sendiri yang terlalu tinggi sama seperti penelitian dari diteliti oleh (Alhasani \& Ogi, 2014), (Ilyas, 2015), (Benaino, et al., 2017), (Budiarto \& Purwanti, 2013), (Kurniawan \& Arianti, 2013), (Bandrang, 2015) dan (Hanafi, et al., 2014). Selain harga dari barang itu sendiri (sedan), perbandingan dari munculnya harga barang lain yang lebih murah dengan kualitas serupa yakni mobil MPV yang didukung penelitian dari (Rusdi \& Suparta, 2016), (Sitorus, et al., 2015) dan (Laely, et al., 2016) yang di mana harga barang lain/pengganti dapat mempengaruhi penjualan suatu barang/produk.

\section{Telaah Pustaka}

\subsection{Pengertian penjualan}

Buku Kamus Istilah Ekonomi (Moekijat, 2000), mengungkapkan bahwa "Penjualan adalah suatu kegiatan yang bertujuan untuk mencari pembeli, mempengaruhi dan memberikan petunjuk agar pembeli dapat menyesuaikan kebutuhannnya dengan produk yang ditawarkan serta mengadakan persetujuan mengenai harga yang menguntungkan bagi kedua belah pihak".

Penjualan dipengaruhi oleh permintaan suatu barang, karena banyaknya permintaan maka banyaklah barang yang diproduksi untuk dijual. Sesuai dengan pembahasan dilatar belakang yaitu Penjualan
Mobil Sedan, maka yang menyebabkan harga sedan tinggi adalah HPP dan tarif PPnBM nya yang besar.

Pengertian dari PPnBM (Pajak Penjualan atas Barang Mewah) menurut Undang-undang Nomor 42 Tahun 2009 Pasal 5 bahwa PPnBM adalah pajak yang dikenakan pada barang yang tergolong mewah yang dilakukan oleh produsen untuk menghasilkan atau mengimpor dalam kegiatan usahanya. Semakin tinggi pengenaan PPnBM pada suatu barang maka akan semakin tinggi pula harga jual barang tersebut. sehingga, hal itu dapat mengakibatkan permintaan barang itu sendiri (sedan) menjadi menurun sesuai dengan teori permintaan. Berdasarkan teori permintaan, menjelaskan tentang ciri hubungan antara jumlah permintaan dan harga (Sukirno, 2000). Jumlah permintaan berkurang jika harganya bertambah dan jumlah permintaan bertambah ketika harganya berkurang sehingga dikatakan bahwa jumlah yang diminta berpengaruh negatif dengan harga (Mankiw, 2000).

\subsection{Faktor-faktor yang mempengaruhi permintaan}

Ada beberapa faktor yang mempengaruhi permintaan suatu barang, antara lain (Sukirno, 2000) harga barang itu sendiri, harga barang pengganti, pendapatan, jumlah penduduk, cita rasa masyarakat/selera, ekspetasi harga pada masa depan, promosi/iklan, persaingan, dan penjualan pada periode sebelumnya.

\subsection{Faktor-faktor yang mempengaruhi penawaran}

Beberapa faktor-faktor yang mempengaruhi penawaran (Daniel, 2004). Diantaranya adalah pajak, teknologi, harga input, jumlah produsen, perkiraan 
harga di masa depan, dan bencana alam .

\subsection{Keseimbangan pasar}

Keseimbangan pasar adalah suatu keadaan saat jumlah produk atau barang yang diminta sama dengan jumlah barang yang ditawarkan pada harga tertentu, yang dapat tercapai jika jumlah produk yang diminta sama dengan jumlah produk yang ditawarkan, atau harga dari produk yang ditawarkan sama dengan harga produk yang diminta oleh konsumen. Saat itu juga akan terjadi transaksi antara penjual dan pembeli, sebab telah terjadi kesepakatan (Sukirno, 2010).

Penelitian terdahulu mengenai pengaruh Penjualan Sebelumnya, Harga Barang Itu Sendiri, dan Harga Barang Pengganti terhadap Penjualan Mobil Sedan. Dalam penelitian tersebut menghasilkan bahwa walaupun iklan dan harga besar tetapi penjualan terus menaik, jadi adanya pengaruh positif signifikan dari iklan dan harga terhadap penjualan mobil Toyota Avanza (Alhasani \& Ogi, 2014).

Selanjutnya, penelitian mengenai pengaruh harga, promosi, dan cabang/perwakilan terhadap penjualan mobil toyota avanza menunjukan adanya pengaruh positif dari harga, promosi, dan cabang/perwakilan terhadap penjualan mobil toyota avanza. variabel cabang/perwakilan mendominan karena semakin bervariasinya tipe mobil maka pembukaan cabang/perwakilan meningkat dan penjualannya pun bertambah walaupun harga mobilnya menaik (Ilyas, 2015).

Berbeda dengan hasil penelitian yang mengenai pengaruh harga terhadap upaya peningkatan penjualan mobil Xenia di mana hasilnya menunjukkan bahwa adanya pengaruh negatif dari harga terhadap penjualan mobil Xenia (Benaino, et al., 2017).

Kemudian penelitian mengenai faktor apa saja yang mempengaruhi permintaan sepeda motor, di mana faktor pendapatan, tarif angkutan umum, dan jumlah anggota keluarga berpengaruh positif, sedangkan faktor harga berpengaruh namun tidak signifikan dan faktor selera berpengaruh terhadap permintaan sepeda motor (Budiarto \& Purwanti, 2013).

Penelitian tentang faktor yang mempengaruhi permintaan mobil Kijang Innova menghasilkan bahwa faktor harga mobil Innova (barang itu sendiri) berpengaruh negatif, faktor pendapatan konsumen berpengaruh positif, faktor pelayanan purna jual tidak begitu berpengaruh, dan faktor harga mobil lain (barang pengganti) tidak berpengaruh terhadap permintaan mobil Kijang Innova (Kurniawan \& Arianti, 2013).

Hasil penelitian mengenai Faktor apa saja yang mempengaruhi permintaan telur ayam ras menunjukkan bahwa harga telur ayam ras (barang itu sendiri), harga ikan asin dan beras (barang pelengkap) berpengaruh negatif, harga ikan bandeng (barang pengganti) dan tingkat pendidikan tidak berpengaruh terhadap permintaan telur ayam ras (Bandrang, 2015).

Penelitian mengenai faktor apa saja yang mempengaruhi permintaan tempe menunjukkan bahwa faktor harga tempe (barang itu sendiri) berpengaruh positif, faktor harga telur (barang pengganti) dan jumlah anggota keluarga tidak berpengaruh terhadap permintaan tempe (Hanafi, et al., 2014).

Penelitian mengenai faktor apa saja yang mempengaruhi permintaan daging sapi, di mana faktor harga daging sapi (barang itu sendiri) dan faktor harga ayam (barang pengganti) berpengaruh positif, faktor PDRB perkapita dan jumlah penduduk berpengaruh positif terhadap permintaan daging sapi (Rusdi \& Suparta, 2016).

Penelitian tentang faktor-faktor yang mempengaruhi permintaan telur ayam di mana faktor harga telur ayam (barang itu sendiri) berpengaruh negatif, faktor pendapatan tidak berpengaruh, faktor jumlah tanggungan berpengaruh positif, dan faktor harga tempe (barang pengganti) berpengaruh positif terhadap permintaan telur ayam. (Sitorus, et al., 2015)

Hasil penelitian tentang faktor apa saja yang mempengaruhi permintaan beras yang menghasilkan bahwa harga beras (barang itu sendiri) dan selera konsumen tidak berpengaruh, sedangkan faktor harga mie instant (barang pengganti), jumlah anggota keluarga, dan pendapatan berpengaruh positif terhadap Permintaan Beras (Laely, et al., 2016).

\subsection{Kerangka konseptual}

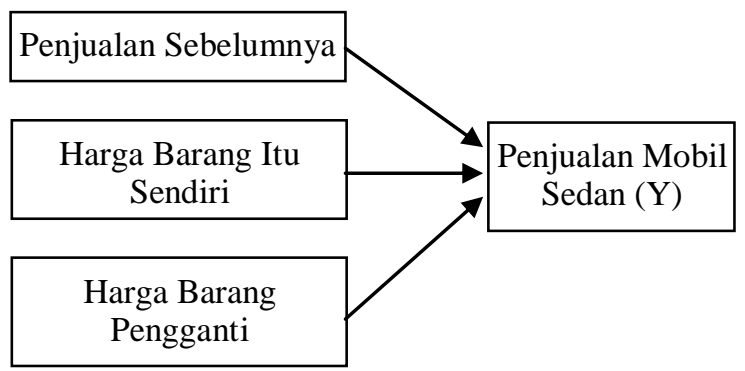

Gambar 1. Kerangka konseptual

\section{Metode penelitian}

\subsection{Variabel dan pengukuran}

\subsubsection{Variabel terikat}

Variabel dependen atau terikat dalam penelitian ini adalah Penjualan Mobil Sedan. Pengukuran nya dilihat dari unit mobil sedan yang berhasil terjual selama rentang waktu penelitian.

\subsubsection{Variabel bebas}

1) Penjualan Sebelumnya. Penjualan sebelumnya dapat mempengaruhi Penjualan Mobil Sedan pada saat itu karena berdasarkan teori inersia menjelaskan bahwa keputusan saat ini dapat dipengaruhi 
oleh kejadian sebelumnya, atau sebaliknya bahwa kejadian saat ini dapat mempengaruhi keputusan apa yang akan ambil di masa depan. Hal itu juga bisa disebut dengan sistem dinamis, yang memiliki artian bahwa sistem yang variabelnya dapat terus berubah dikarenakan perubahan input dan interaksi antar elemen pada sistem. Dengan kata lain, nilai output sangat bergantung pada niai variabelvariabel input sebelumnya. (Djojormartono, 2009). Jadi, jika penjualan sebelumnya turun maka penjualan saat ini bisa turun, begitu pula dengan sebaliknya. Oleh karena itu, dapat dibuat hipotesa sebagai berikut:

H1 : Penjualan Sebelumnya berpengaruh negatif terhadap Penjualan Mobil Sedan

2) Harga Barang Itu Sendiri. Pada penelitian sebelumnya yang diteliti (Benaino, et al., 2017), (Sitorus, et al., 2015), (Bandrang, 2015), dan (Kurniawan \& Arianti, 2013) harga berpengaruh negatif terhadap penjualan mobil/permintaan suatu produk. Berbeda dengan penelitian dari (Alhasani \& Ogi, 2014), (Ilyas, 2015), (Rusdi \& Suparta, 2016), dan (Hanafi, et al., 2014) menunjukkan bahwa harga berpengaruh positif terhadap penjualan mobil/permintaan suatu produk. Sedangkan hasil penelitian (Budiarto \& Purwanti, 2013) harga tidak begitu berpengaruh, (Laely, et al., 2016) tidak berpengaruh terhadap permintaan produk. Karena hasil penelitiannya berbeda-beda, jadi harus menganut pada teori permintaan yaitu permintaan bisa menurun ketika harganya meningkat dan permintaan meningkat ketika harganya menurun sehingga dapat dikatakan bahwa permintaan berhubungan secara negatif dengan harga (Mankiw, 2000). Oleh karena itu, dapat dibuat hipotesa sebagai berikut:

H2: Harga Barang Itu Sendiri berpengaruh negatif terhadap Penjualan Mobil Sedan

Pengukuran harga dapat dilihat dari rata-rata harga mobil Sedan 1501-3000cc dengan tarif pajak 30\% secara kuartalan selama 5 tahun dari 2013-2017 dibagi dengan Indeks Harga Konsumen dikali 100.

$$
\frac{\text { Rata - rata harga sedan }}{\text { Indeks harga konsumen }} \times 100
$$

3) Harga Barang Pengganti/Subsitusi. Variabel bebas yang kedua adalah Harga Barang Pengganti/ Substitusi. Hasil penelitian dari (Rusdi \& Suparta, 2016), (Sitorus, et al., 2015) dan (Laely, et al., 2016) mengenai pengaruh harga tempe (barang substitusi) terhadap jumlah permintaan telur ayam, di mana harga tempe berpengaruh positif terhadap permintaan. Berbeda dengan penelitian dari (Kurniawan \& Arianti, 2013), (Bandrang, 2015), dan (Hanafi, et al., 2014) dan bahwa harga barang pengganti tidak berpengaruh terhadap permintaan suatu produk. Oleh karena itu, harus disesuaikan dengan teori ekonomi yaitu jika harga suatu barang naik maka orang akan mencari barang lain yang fungsinya sama, tetapi harganya lebih murah. Sehingga harga barang subsitusi berpengaruh positif terhadap permintaan suatu barang (Ida, 2009). Jadi, dapat dibuat hipotesa sebagai berikut:

H3: Harga Barang Pengganti berpengaruh positif terhadap Penjualan Mobil Sedan

Pengukuran harga dapat dilihat dari rata-rata harga mobil MPV 1501-2500cc secara kuartalan selama 5 tahun dari 2013-2017 dibagi dengan Indeks Harga Konsumen dikali 100.

$$
\frac{\text { Rata }- \text { rata harga mpv }}{\text { Indeks harga konsumen }} \times 100
$$

\subsection{Populasi dan sampel}

Populasi yang menjadi objek penelitian ini adalah perusahaan mobil sedan yang tercatat di data Gaikindo. Sedangkan untuk sampelnya dapat diambil menggunakan metode tertentu. Pengambilan sampel dalam penelitian ini yaitu dengan menggunakan metode purpossive sampling dengan kriteria sampel yang dibuat, kriteria tersebut adalah sebagai berikut:

Tabel 3. Kriteria dan hasil purpossive sampling

\begin{tabular}{|l|c|}
\hline \multicolumn{1}{|c|}{ Kriteria Sampel } & Jumlah \\
\hline $\begin{array}{l}\text { Perusahaan mobil sedan yang tercatat di } \\
\text { GAIKINDO selama rentang waktu penelitian }\end{array}$ & 24 \\
\hline $\begin{array}{l}\text { Pengurangan Kriteria 1: Jumlah Perusa- } \\
\text { haan mobil sedan yang berkapasitas mesin } \\
\text { 1501-3000cc }\end{array}$ & (5) \\
\hline $\begin{array}{l}\text { Pengurangan Kriteria 2: Perusahaan mobil } \\
\text { sedan yang memiliki penjualan terbesar di } \\
\text { antara merk lainnya }\end{array}$ & (13) \\
\hline $\begin{array}{l}\text { Pengurangan Kriteria 3: Perusahaan mobil } \\
\text { sedan yang mengalami kenaikkan perkuartal- } \\
\text { nya setiap tahun }\end{array}$ & $(1)$ \\
\hline Total Sampel & $\mathbf{5}$ \\
\hline
\end{tabular}

Sumber: www.gaikindo.or.id (2019)

Berdasarkan kriteria diatas maka perusahaan yang dapat dijadikan sampel dalam penelitian ini adalah Toyota, BMW, Honda, Mazda, Nissan.

\subsection{Analisis data}

Metode yang digunakan penelitian ini adalah metode analisis regresi panel data yang memiliki jumlah gabungan antara data runtut waktu (time series) dan data silang (cross section) (Basuki, 2016). Model persamaan data panel adalah sebagai berikut:

$\begin{aligned} \text { SALES }_{i t}= & \beta_{0}+\beta_{1} \text { SALESSEB }_{i t}-\beta \text { HBIS }_{2 i t}+\beta_{3} \text { HBP }_{i t} \\ & +e_{i t}\end{aligned}$

Keterangan:

SALES : Penjualan Mobil Sedan

$\beta_{1}, \beta_{2}, \beta_{3} \quad$ : Koefisien regresi

SALESSEB : Penjualan Sebelumnya

HBIS : Harga Barang Itu Sendiri

HBP : Harga Barang Pengganti/Substitusi

a $\quad$ : Konstanta 
e $\quad$ : Error (Kesalahan)

$i \quad:$ Entitas ke-i

$t \quad:$ Periode ke-t

Dalam menganalisis data ini memerlukan beberapa langkah yang harus dilakukan yaitu dengan menggunakan 3 metode, adalah Common Effect (Ordinary Least Square), Fixed Effect, dan Random Effect melalui chow test, hausman test, dan LM (Lagrange Multiplier). Setelah itu dapat diinterpretasikan secara tepat dengan cara uji hipotesis dan uji kecocokan model (Basuki, 2016).

\section{Hasil Penelitian dan Pembahasan}

\subsection{Deskripsi data}

Berdasarkan Tabel 3 dapat dilihat bahwa besarnya nilai Penjualan Mobil Sedan pada 2013-2017 berfluktuatif. Penjualan tertinggi selama periode 2013-2017 yaitu perusahaan Toyota, sedangkan perusahaan yang memiliki Penjualan terendah adalah Nissan.

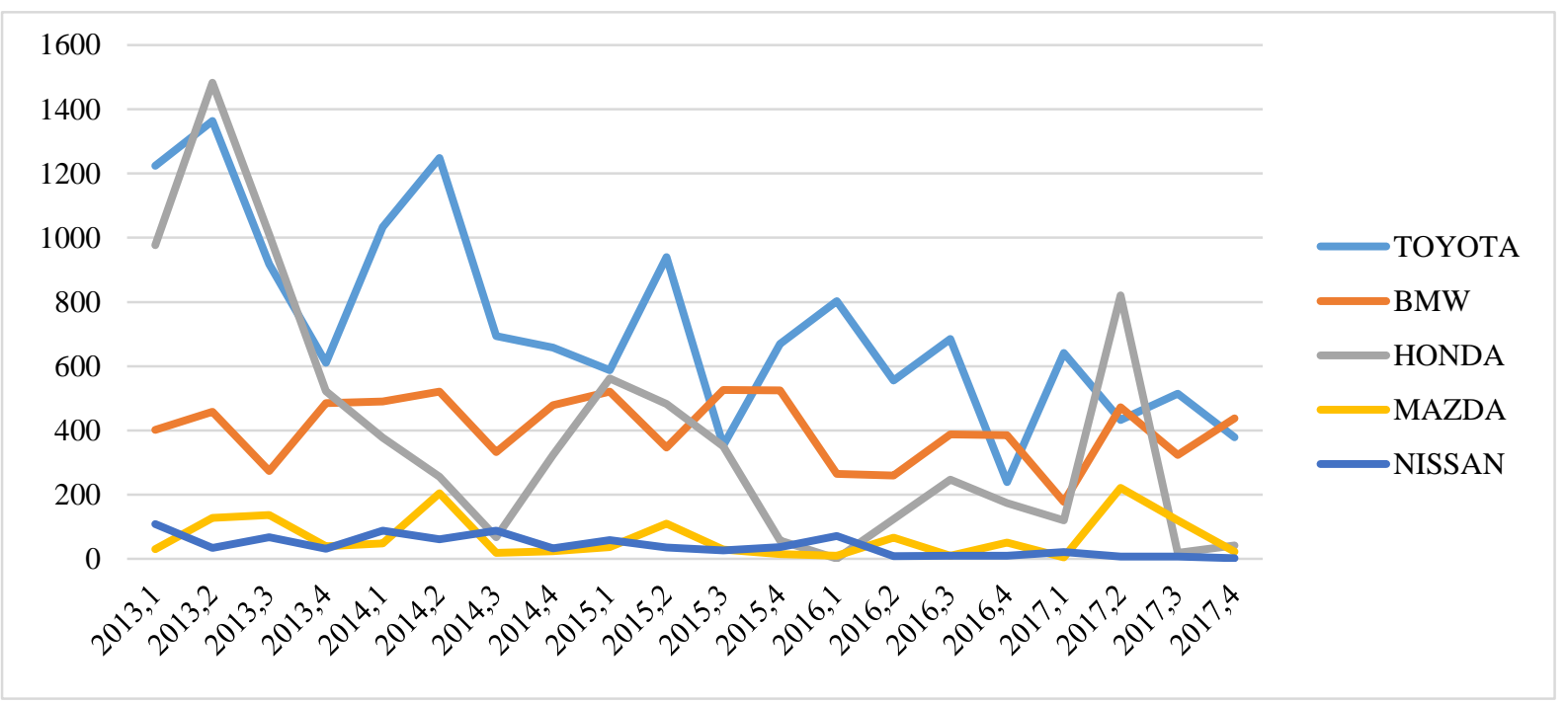

Gambar 2. Pergerakan total penjualan mobil sedan periode 2013-2017 (data kuartal)

Sumber: Data olahan (2019)

Pergerakan Penjualan Sebelumnya dapat dilihat di Gambar 2 bahwa penjualan mobil dari tahun ketahun mengalami naik dan turun yang sama, ketika menurun maka perode selanjutnya akan menurun atau menaik tetapi tidak signifikan karena sudah pernah mengalami penurunan yang signifikan.
Berdasarkan Gambar 3 dapat dilihat Harga Barang Itu Sendiri/mobil sedan mengalami fluktuasi selama periode 2013-2017 pada perusahaan mobil sedan. Harga sedan tertinggi dicapai oleh perusahaan BMW dengan rata-rata harga Rp 1 miliar. Kemudian, untuk rata-rata harga jual yang paling rendah dikeluarkan oleh perusahaan Honda.

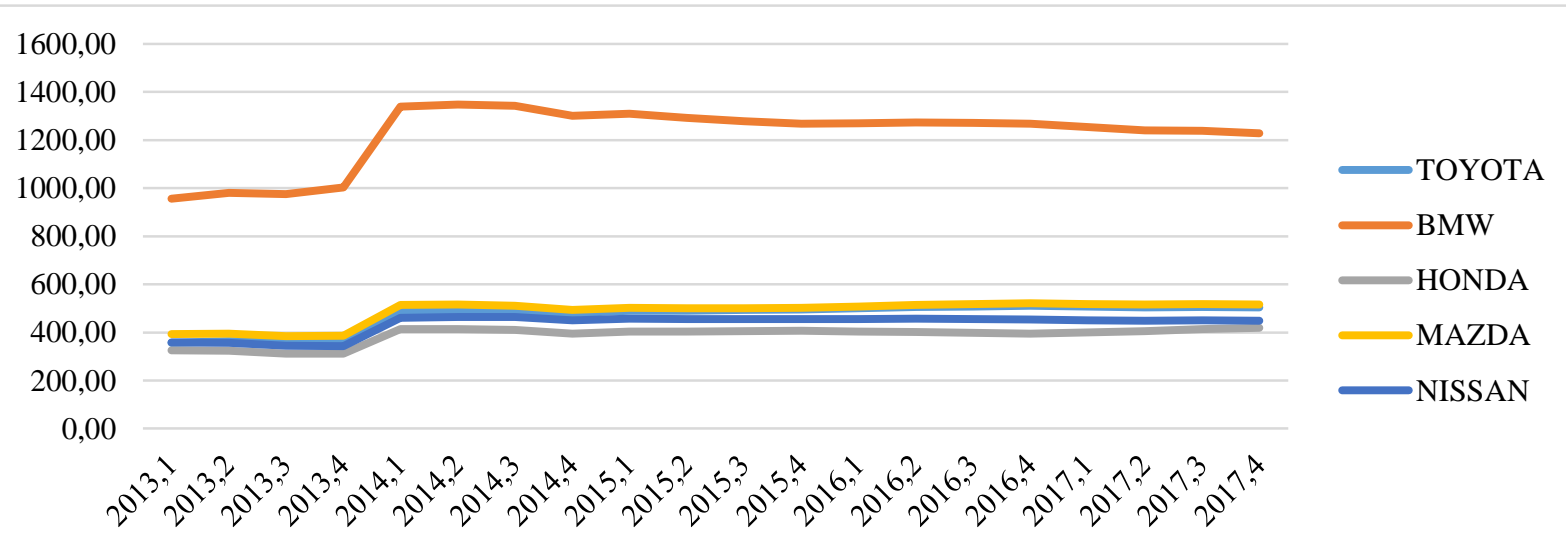

Gambar 3. Pergerakan rata-rata harga mobil sedan periode 2013-2017 (data kuartal) Sumber: Data olahan (2019)

Pada Gambar 4 berikut, menunjukkan grafik harga MPV guna membandingkan perubahan harga
MPV dari tahun ketahun. Harga Barang Pengganti atau MPV tertinggi yaitu pada kuartal 4 tahun 2016 
sebesar Rp 342 juta.

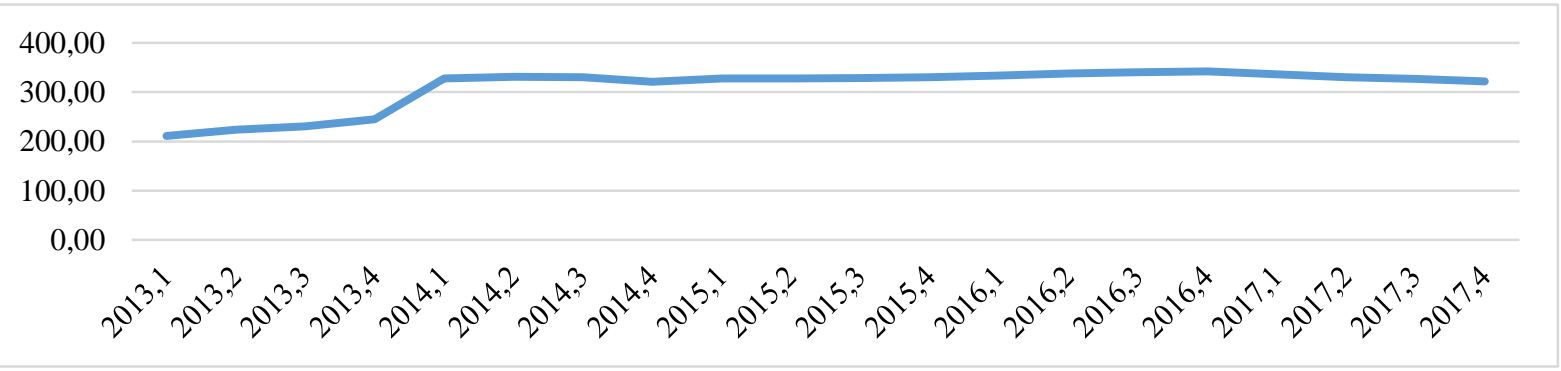

Gambar 4. Pergerakan rata-rata harga MPV periode 2013-2017 (data kuartal)

Sumber: Data olahan (2019)

\subsection{Hasil analisis data panel}

Analisis yang digunakan dalam peneitian ini yaitu analisis regresi panel data. Dalam metode ini, menggunakan 3 pendekatan estimasi untuk menguji dan menentukan model apa yang tepat untuk penelitian ini. Tiga pendekatan tersebut diantaranya adalah Common Effect, Fixed Effect, dan Random Effect melalui Uji Chow Uji Hausman, dan Uji LM.

Tabel 4. Hasil estimasi

\begin{tabular}{|c|c|c|c|c|}
\hline \multirow{2}{*}{ Variabel } & \multirow{2}{*}{ Hipotesa } & \multicolumn{3}{|c|}{ Koefisien } \\
\hline & & Common Effect & Fixed Effect & Random Effect \\
\hline Konstanta & & 255.9912 & 514.5899 & 255.9912 \\
\hline Penjualan Sebelumnya & + & $0.750287 *$ & $0.352795 *$ & $0.750287 *$ \\
\hline Harga Barang itu Sendiri & - & 0.051752 & $1.094902 *$ & 0.051752 \\
\hline Harga Barang Pengganti & + & -0.693756 & $-3.110383^{*}$ & -0.693756 \\
\hline $\mathrm{R}$-Squared & & 0.631723 & 0.710942 & 0.631723 \\
\hline Adjusted $\mathrm{R}$-Square & & 0.620214 & 0.688948 & 0.620214 \\
\hline F-Statistic & & $54.89105 *$ & $32.32502 *$ & $54.89105^{*}$ \\
\hline Uji Chow & & $24.220847^{*}$ & \multicolumn{2}{|c|}{ Fixed Effect } \\
\hline Uji Hausman & & $25.159037 *$ & \multicolumn{2}{|c|}{ Fixed Effect } \\
\hline
\end{tabular}

Sumber: Data olahan (2019)

Setelah melakukan Uji Chow dan Uji Hausman maka yang terpilih adalah fixed effect model karena angka yang dihasilkan signifikan.

Langkah berikutnya, yaitu Koefisien Determinasi atau Adjusted R-squared. Ajusted Rsquared sebesar 0.68 atau $68 \%$ yang mengandung arti bahwa kemampuan variabel independen dalam mempengaruhi variabel dependen sebanyak $68 \%$ sedangkan $32 \%$ nya dipengaruhi oleh variabel independen lain diluar penelitian ini.

Langkah berikutnya, yaitu melakukan Uji Hipotesis. Dalam uji hipotesis terbagi dua, yaitu Uji Simultan (Uji f), dan Uji Parsial (Uji t). Hasil dari Uji F menghasilkan angka yang signifikan, yang itu berarti adanya pengaruh dari variabel Penjualan Sebelumnya, Harga Barang Itu Sendiri, dan Harga Barang Pengganti terhadap Penjualan Mobil Sedan di Indonesia.

Berdasarkan Tabel 4, untuk mengetahui hasil Uji t yaitu dengan meihat dari kolom Fixed Effect.

1) Penjualan sebelumnya, prob. yang dihasilkan dalam variabel tersebut adalah signifikan dengan koefisien sebesar 0.352795 , itu berarti variabel penjualan sebelumnya berpengaruh positif terhadap penjualan sedan.

2) Harga barang itu sendiri/mobil sedan dengan prob. yang dihasilkan variabel tersebut adalah signifikan dengan koefisien sebesar 1.094902, itu berarti variabel harga barang itu sendiri berpengaruh positif terhadap penjualan sedan.

3) Harga barang pengganti/mobil mpv dengan prob. yang dihasilkan variabel tersebut adalah signifikan dengan koefisien sebesar -3.110383, itu berarti variabel harga barang pengganti berpengaruh negatif terhadap Penjualan Sedan.

\subsection{Pembahasan pengaruh penjualan sebelumnya terhadap penjualan mobil sedan}

Penjualan Sebelumnya berpengaruh terhadap Penjualan Sedan di Indonesia periode 2013-2017 dengan data kuartal. Oleh sebab itu, dapat disimpulkan bahwa adanya pengaruh positif dari Penjualan Sebelumnya terhadap Penjualan Sedan.

Hasil tersebut sesuai dengan hipotesis 1 dari teori inersia dan sistem dinamis bahwa kejadian pada saat ini dipengaruhi oleh kejadian pada sebelumnya, begitupun sebaliknya bahwa kejadian saat ini bisa mempengaruhi kejadian di masa yang akan datang. Sama hal nya dengan penelitian ini, jika penjualan 
sedan pada periode sebelumnya turun, maka penjualan sedan pada saat ini bahkan selanjutnya bisa ikut turun karena segala sesuatu yang terjadi pada waktu sebelumnya bisa mempengaruhi kejadian di masa yang akan datang, begitu pula sebaliknya.

\subsection{Pembahasan pengaruh harga barang itu sendiri terhadap penjualan mobil sedan}

Harga Barang Itu Sendiri berpengaruh terhadap Penjualan Sedan di Indonesia Periode 2013-2017. Berdasarkan hasil olah data, menunjukkan prob. Harga Barang Itu Sendiri (HBIS) sebesar 0.0453 yang berarti $<0.05$, dengan koefisien yang dihasilkan sebesar 1.094902. Oleh sebab itu, dapat disimpulkan bahwa Harga Barang Itu Sendiri berpengaruh positif terhadap Penjualan Sedan. Hal itu bertentangan dengan hipotesis 2 karena menurut teori ekonomi, menegaskan bahwa semakin tinggi harga maka permintaan semakin turun yang menyebabkan adanya pengaruh negatif antara harga dan permintaan, tetapi dalam penelitian ini berbanding terbalik. Jika dilihat dari data quartal nya, lebih dari 50\% ketika harga sedan naik penjualan pun naik tetapi jika harga turun maka penjualan juga turun. Itu bisa dikarenakan masyarakat Indonesia yang masih minat dengan sedan adalah masyarakat yang menengah atas atau high class, jadi semakin tinggi harga sedan maka semakin semakin mewah dan bergengsi sedan tersebut yang membuat konsumen high class semakin tertarik membeli sedan, bisa jadi untuk koleksi atau variasi sedan yang semakin tahun semakin elegant.

Hasil penelitian ini sejalan dengan hasil penelitian dari (Alhasani \& Ogi, 2014), (Ilyas, 2015), (Rusdi \& Suparta, 2016), dan (Hanafi, et al., 2014) yang menunjukkan bahwa Harga Barang Itu Sendiri berpengaruh positif terhadap Penjualan Mobil/ Permintaan suatu produk, bahwa semakin tinggi harga maka penjualan pun semakin naik dengan berbagai alasan. Karena itu kebutuhan pokok, gengsi, percaya dengan brand, atau musim.

Hasil penelitian ini tidak sejalan dengan penelitian dari (Benaino, et al., 2017), (Sitorus, et al., 2015), (Bandrang, 2015), dan (Kurniawan \& Arianti, 2013) bahwa Harga berpengaruh negatif terhadap Penjualan mobil/Permintaan suatu produk, hasil penelitian dari mereka sesuai dengan teori ekonomi yang berlaku bahwa semakin tinggi harga maka semakin turun penjualan suatu produk. Hal itu biasanya dikarenakan pendapatan masyarakat atau adanya barang pengganti yang lebih murah namun memiliki fungsi yang serupa dengan barang itu sendiri.

\subsection{Pembahasan pengaruh harga barang pengganti terhadap penjualan sedan}

Harga MPV berpengaruh terhadap Penjualan Sedan. Berdasarkan hasil olah data, menunjukkan prob. Harga Barang Pengganti (HBP) sebesar 0.0018 itu berarti $<0.05$, sedangkan koefisien yang dihasilkan adalah -3.110383. Oleh sebab itu, dapat disimpulkan bahwa adanya pengaruh negatif dari Harga MPV terhadap Penjualan Sedan. Hal itu bertentangan dengan hipotesis 3 karena teori ekonomi mengatakan ketika harga barang pengganti turun maka permintaan akan barang lain pun menurun yang berarti adanya pengaruh positif antara harga barang pengganti terhadap permintaan. Tetapi hasil penelitian ini berpengaruh namun bertentangan oleh hipotesis, hal itu terjadi karena ketika Harga Mobil jenis lain naik maka Penjualan Sedan akan tetap turun karena jika dilihat dari pangsa pasar mobil sedan dan MPV pun berbeda, mobil sedan peminatnya adalah orang yang high class dan peminat MPV hanya orang-orang yang kelas menengah, sedangkan mayoritas masyarakat Indonesia adalah masyarakat golongan kelas menengah. Jadi, walaupun harga MPV naik maka penjualan MPV masih bisa naik dan jika penjualan MPV naik maka penjualan Sedan menjadi turun, karena senaiknaiknya harga MPV masih jauh dibawah harga sedan. Begitu pula sebaliknya, seturun-turunnya harga sedan masih jauh diatas harga MPV. Oleh sebab itu, adanya pengaruh negatif antara Harga MPV dengan Penjualan Sedan didalam penelitian ini.

Hasil penelitian ini selain bertentangan dengan Hipotesis 3, hasil ini juga tidak sejalan dengan hasil penelitian terdahulu dari (Rusdi \& Suparta, 2016), (Sitorus, et al., 2015), dan (Laely, et al., 2016) mengenai faktor-faktor yang mempengaruhi permintaan suatu produk di mana harga barang pengganti berpengaruh positif terhadap permintaan, karena semakin turun harga barang pengganti maka permintaan suatu produk ikut menurun begitupun sebaliknya. Hasil penelitian ini juga bertentangan dengan penelitian dari (Kurniawan \& Arianti, 2013), (Bandrang, 2015), dan (Hanafi, et al., 2014) bahwa Harga Barang Pengganti tidak berpengaruh terhadap Permintaan suatu produk, karena walaupun harga barang pengganti turun tetapi tidak mempengaruhi permintaan suatu barang karena konsumen memang lebih membutuhkan barang lain tersebut dibanding barang pengganti atau karena faktor pendapatan, walaupun harga barang itu sendiri dan harga barang pengganti sama-sama murah maka konsumen tidak membeli ke dua barang tersebut karena tidak sesuai dengan pendapatan mereka.

Tabel 5. Penerimaan PPnBM mobil sedan dan mobil MPV periode 2013-2017 


\begin{tabular}{|c|c|c|c|c|c|c|c|c|}
\hline Periode & $\begin{array}{l}\text { Pejualan } \\
\text { Sedan } \\
\text { (Unit) }\end{array}$ & $\begin{array}{l}\text { Harga } \\
\text { Sedan } \\
\text { (Juta Rp) }\end{array}$ & $\begin{array}{l}\text { Tarif } \\
\text { PPnBM } \\
\text { Sedan } \\
(\%)\end{array}$ & $\begin{array}{l}\text { Penerimaan } \\
\text { PPnBM } \\
\text { Sedan } \\
\text { (Milyar } \\
\text { Rp) }\end{array}$ & $\begin{array}{l}\text { Penjualan } \\
\text { MPV } \\
\text { (Unit) }\end{array}$ & $\begin{array}{l}\text { Harga } \\
\text { MPV } \\
\text { (Juta Rp) }\end{array}$ & $\begin{array}{l}\text { Tarif } \\
\text { PPnBM } \\
\text { MPV } \\
(\%)\end{array}$ & $\begin{array}{l}\text { Penerimaan } \\
\text { PPnBM } \\
\text { MPV } \\
\text { (Milyar } \\
\text { Rp) }\end{array}$ \\
\hline 2013.1 & 2.740 & 478.15 & 40 & 3.743 & 24.051 & 211.34 & 20 & 847 \\
\hline 2013.2 & 3.466 & 484.07 & 40 & 4.794 & 23.517 & 224.11 & 20 & 486 \\
\hline 2013.3 & 2.405 & 475.18 & 40 & 3.265 & 20.116 & 230.40 & 20 & 1.324 \\
\hline 2013.4 & 1.688 & 481.92 & 40 & 2.324 & 23.230 & 244.67 & 20 & 772 \\
\hline \multicolumn{4}{|c|}{ Total Pertahun } & 14.126 & \multicolumn{3}{|c|}{ Total Pertahun } & 2.106 \\
\hline
\end{tabular}

\begin{tabular}{|c|c|c|c|c|c|c|c|c|}
\hline Periode & $\begin{array}{l}\text { Pejualan } \\
\text { Sedan } \\
\text { (Unit) }\end{array}$ & $\begin{array}{l}\text { Harga } \\
\text { Sedan } \\
\text { (Juta Rp) }\end{array}$ & $\begin{array}{l}\text { Tarif } \\
\text { PPnBM } \\
\text { Sedan } \\
(\%)\end{array}$ & $\begin{array}{l}\text { Penerimaan } \\
\text { PPnBM } \\
\text { Sedan } \\
\text { (Milyar } \\
\text { Rp) } \\
\end{array}$ & $\begin{array}{l}\text { Penjualan } \\
\text { MPV } \\
\text { (Unit) }\end{array}$ & $\begin{array}{l}\text { Harga } \\
\text { MPV } \\
\text { (Juta Rp) }\end{array}$ & $\begin{array}{l}\text { Tarif } \\
\text { PPnBM } \\
\text { MPV } \\
(\%)\end{array}$ & $\begin{array}{l}\text { Penerimaan } \\
\text { PPnBM } \\
\text { MPV } \\
\text { (Milyar } \\
\text { Rp) }\end{array}$ \\
\hline 2014.1 & 2.036 & 643.06 & 40 & 3.741 & 16.954 & 327.55 & 20 & 925 \\
\hline 2014.2 & 2.290 & 647.09 & 40 & 4.234 & 18.592 & 330.67 & 20 & 1.025 \\
\hline 2014.3 & 1.201 & 644.08 & 40 & 2.210 & 15.343 & 330.20 & 20 & 844 \\
\hline 2014.4 & 1.517 & 623.86 & 40 & 2.704 & 12.732 & 320.87 & 20 & 681 \\
\hline \multicolumn{4}{|c|}{ Total Pertahun } & 12.889 & \multicolumn{3}{|c|}{ Total Pertahun } & 2.451 \\
\hline 2015.1 & 1.765 & 632.09 & 40 & 3.187 & 13.527 & 327.27 & 20 & 738 \\
\hline 2015.2 & 1.913 & 628.84 & 40 & 3.437 & 13.667 & 327.75 & 20 & 746 \\
\hline 2015.3 & 1.284 & 626.42 & 40 & 2.298 & 11.188 & 328.64 & 20 & 613 \\
\hline 2015.4 & 1.301 & 625.20 & 40 & 2.324 & 13.363 & 330.15 & 20 & 735 \\
\hline \multicolumn{4}{|c|}{ Total Pertahun } & 11.246 & \multicolumn{3}{|c|}{ Total Pertahun } & 2.832 \\
\hline 2016.1 & 1.083 & 627.06 & 40 & 1.940 & 17.554 & 333.56 & 20 & 976 \\
\hline 2016.2 & 1.011 & 630.09 & 40 & 1.820 & 15.151 & 337.62 & 20 & 852 \\
\hline 2016.3 & 1.338 & 630.24 & 40 & 2.409 & 14.360 & 340.15 & 20 & 814 \\
\hline 2016.4 & 857 & 629.55 & 40 & 1.541 & 13.930 & 342.25 & 20 & 794 \\
\hline \multicolumn{4}{|c|}{ Total Pertahun } & 7.710 & \multicolumn{3}{|c|}{ Total Pertahun } & 3.436 \\
\hline 2017.1 & 964 & 625.96 & 40 & 1.724 & 15.040 & 335.95 & 20 & 842 \\
\hline 2017.2 & 1.520 & 622.55 & 40 & 2.704 & 15.965 & 329.83 & 20 & 877 \\
\hline 2017.3 & 984 & 624.70 & 40 & 1.756 & 19.335 & 326.72 & 20 & 1.052 \\
\hline 2017.4 & 881 & 622.89 & 40 & 1.568 & 20.177 & 321.56 & 20 & 1.081 \\
\hline \multicolumn{4}{|c|}{ Total Pertahun } & 7.752 & \multicolumn{3}{|c|}{ Total Pertahun } & 1.721 \\
\hline
\end{tabular}

Sumber: www.gaikindo.or.id (2019)

\subsection{Prediksi PPnBM pada mobil sedan dan MPV}

Sesuai dengan tujuan penelitian yaitu penelitian ini memiliki tujuan guna memprediksi penerimaan PPnBM antara mobil sedan dengan mobil MPV, dan membandingkan lebih besar penerimaan PPnBM mobil sedan dengan tarif pajak yang besar namun penjualan sedikit atau lebih besar penerimaan PPnBM mobil MPV dengan tarif pajak yang kecil namun penjualan nya banyak. Dengan besarnya penerimaan PPnBM maka akan berdampak positif bagi negara karena semakin tinggi penerimaan PPnBM maka penghasilan suatu negara pun meningkat, tetapi jika penerimaan PPnBM kecil maka penghasilan negara menurun. Oleh karena itu, akan disajikan perhitungan penerimaan PPnBM berdasarkan total penjualan mobil per kuartal selama 2013-2017 setelah disesuaikan dengan kriteria sanpel pada Tabel 5 .

Berdasarkan Tabel 5, dapat disimpulkan bahwa PPnBM mobil sedan meraih penerimaan tertinggi sebesar Rp 14.126 Milyar di tahun 2013 sedangkan mobil MPV meraih angka tertinggi hanya sebesar Rp 3.436 di tahun 2016, angka tersebut jauh lebih rendah dibandingkan penerimaan PPnBM mobil sedan. Itu berarti penjualan sedan berperan besar dalam penghasilan negara karena penerimaan PPnBM nya cukup tinggi dengan tarif mobil sedan untuk kapasitas mesin 1501-3000 cc sebesar 40\% dan untuk mobil MPV dikenakan tarif 20\% untuk kapasitas mesin yang sama sesuai dengan kriteria sampel. Oleh sebab itu, timbulnya permasalahan bagi negara jika sedan tidak di produksi lagi karena penjualan sedan yang berkapasitas mesin 1501-3000cc memiliki peran yang paling dominan dalam penghasilan negara.

Perbandingan penerimaan PPnBM mobil sedan dan mobi MPV terpaut jauh, itu dikarenakan tarif mobil sedan yang lebih besar dua kali lipat dari tarif PPnBM MPV ditambah lagi harga jual mobil sedan juga lebih mahal daripada mobil MPV yang menyebabkan selisih jauh angka penerimaan PPnBM 
antara kedua jenis mobil tersebut. Oleh sebab itu, dengan turunnya penjualan mobil sedan tidak begitu mempengaruhi kecilnya angka penerimaan PPnBM karena walaupun penjualan mobil sedan selalu menurun yang menyebabkan penerimaan PPnBM nya juga menurun, tetapi angka yang dihasilkan penerimaan PPnBM mobil sedan masih tergolong sangat besar karena harga jual dan tarif PPnBM nya sangat tinggi.

\section{Simpulan}

Penelitian mengenai Faktor-Faktor yang Mempengaruhi Permintaan Mobil Sedan di Indonesia dan Prediksi Pajak Penjualan atas Barang Mewah periode 2013-2017 (dengan data kuartal), maka dapat diperoleh kesimpulan sebagai berikut:

1) Penjualan Sebelumnya berpengaruh positif terhadap Penjualan Mobil Sedan di Indonesia dari lima perusahaan terpilih periode 2013-2017 dengan data kuartal.

2) Harga Barang Itu Sendiri berpengaruh positif terhadap Penjualan Mobil Sedan di Indonesia dari dari lima perusahaan terpilih yang berkapasitas mesin 1501-3000cc periode 2013-2017 dengan data kuartal.

3) Harga Barang Pengganti berpengaruh negatif terhadap Penjualan Mobil Sedan di Indonesia dari seluruh merk MPV berkapasitas mesin 15013000cc periode 2013-2017 dengan data kuartal.

4) Prediksi Pajak Penjualan atas Barang Mewah (PPnBM) antara mobil sedan dan MPV menghasilkan bahwa penerimaan PPnBM mobil sedan jauh lebih tinggi daripada penerimaan PPnBM mobil MPV, sehingga walaupun penjualan mobil sedan menurun maka tidak menyebabkan penerimaan PPnBM mengecil.

\section{Saran}

Dari hasil penelitian ini perusahaan diharapkan untuk meningkatkan kembali kualitas produk dalam mobil

\section{Referensi}

Ajija, S. R., 2011. Cara Cerdas Menguasai Eviews. Jakarta: Salemba Empat.

Alhasani, A. \& Ogi, I., 2014. Pengaruh Iklan dan Harga Terhadap Penjualan Mobil Toyota Avanza pada PT Hajrat Abadi Manado Tahun 20082013. Jurnal EMBA Fakultas Ekonomi dan Bisnis, Jurusan Manajemen Universitas Ratulangi Manado, 2(2), 1021-1031

Bandrang, T. N., 2015. Analisis Permintaan Telur Ayam Ras di Kalimantan Tengah. Jurnal Mimbar Agribisnis, 1(1), 55-63

Basuki, A. T. \&. P. N., 2016. Dalam: Analisis Regrei Dalam Penelitian Ekonomi dan Bisnis: Dilengkapi Aplikasi SPSS \& EVIEWA. depok: PT Rajagrafindo Persada.

Benaino, C. A., Tampy, J. R. \& Tumbel, T. M., 2017. Pengaruh Harga Terhadap Upaya Peningkatan yang akan dipasarkan, karena dilihat dari total penjualan sebelumnya yang berpengaruh terhadap total penjualan di masa berikutnya, jika penjualan kemarin turun maka akan membuat penjualan selanjutnya ikut menurun. Oleh sebab itu, hal ini merupakan tugas tambahan bagi perusahaan mobil sedan bagaimana cara nya supaya konsumen terus tertarik untuk membeli mobil sedan, dengan cara meningkatkan promosi yang harus dikeluarkan, mengubah desain mobil yang lebih modern dan elegant, meperbanyak bengkel resmi, meningkatkan layanan purna jual, memperbanyak cabang/outlet, dan sebagainya.

Bagi pemerintah, hasil ini dapat digunakan untuk melihat perkembagan prediksi penerimaan PPnBM bahwa mobil sedan dan MPV memiliki pangsa pasar yang berbeda, di mana mobil sedan pangsa pasarnya adalah masyarakat golongan menengah keatas sedangkan pangsa pasar mobil MPV masyarakat golongan menengah biasa. Jadi, semakin besar kapasitas mesin dari mobil sedan maka semakin mewah dan mahal mobil tersebut, sehingga peminatnya juga banyak yang berdampak pada penerimaan PPnBM, begitu juga untuk MPV.

Saran bagi peneliti selanjutnya diharapkan untuk memakai variabel independen lain seperti selera, iklan/promosi atau harga barang komplementer supaya hasil adjusted R-squared nya menghasilkan angka yang lebih tinggi, dan memiliki hasil penelitian yang searah dengan hipotesa daripada yang yang dihasilkan dari penelitian ini. Bagi peneliti selanjutnya bisa merubah kriteria sampel dengan menggunakan mobil sedan dan MPV yang berkapasitas mesin <1500cc dan menggunakan data pertahun agar seimbang dengan jumlah cross section. Bagi peneliti selanjutnya bisa menggunakan produk lain selain mobil karena dalam penelitian ini ditemukannya kesulitan untuk mencari harga sedan dan penelitian terdahulu terkait permintaan mobil.

Penjualan Mobil Xenia Pada PT Astra Daihatsu Tbk Cabang Malalayang Manado Tahun 20142016. Jurnal Administrasi Bisnis, 5(3), 1-9

Budiarto, A. \& Purwanti, E. Y., 2013. Faktor-faktor Yang Mempengaruhi Permintaan Sepeda Motor Di Semarang Tahun 2013. Diponegoro Journal of Economics, 2(3), 1-11

Daniel, G., 2004. Kecerdasan Emosional. Jakarta: Gramedia Pustaka Utama.

Dirgantoro, D. P., www.otodriver.com/article/view/ daftar-harga-toyota-terbaru-agustus-2016/. [Diakses Agustus 2016].

Djojormartono, M., 2009. Bahan Kuliah Dasar-Dasar Analisis Sistem Dinamik (tidak dipublikasikan). Bogor: Pogram Pascasarjana, Intititut Pertanian Bogor. 
Ghozali, I., 2009. Aplikasi Analisis Multivariate Dengan Program SPSS. Semarang: Badan Penerbit Universitas Diponegoro.

Hanafi, F. I., Haris, E. \& Rochaeni, S., 2014. Faktorfaktor Yang Mempengaruhi Permintaan Tempe di Jurangmangu Timur Tahun 2013. Jurnal Agribisnis, 8(1), 45-58

Ida, M. B., 2009. Demografi Umum. Yogyakarta: Pustaka Pelajar Offset.

Ilyas, M. I. F., 2015. Pengaruh Harga, Promosi dan Cabang/Perwakilan Terhadap Peningkatan Penjualan Mobil Toyota Avanza di PT Hadji Kalla, Cabang Allaudin Makassar Tahun 20102014. AKMEN Jurnal Ilmiah, 13(2).

Karlinger, 2006. Asas-asas Penelitian Behaviour. 3 penyunt. Yogyakarta: Gadjah Mada University Press.

Kasmir, 2012. Kewirausahaan. Cetakan ke 7 penyunt. Jakarta: PT Raja Grafindo Persada.

Kurniawan, B. A. \& Arianti, F., 2013. Analisis Faktor-Faktor Yang Mempengaruhi Permintaan Mobil Toyota Kijang Inova di Kota Semarang Tahun 2007-2009. Diponegoro Journal of Economics, 2(1), 1-6

Laely, Z., Prastiwi, W. D. \& Setiyawan, H., 2016. Analisis Faktor-Faktor Yang Mempengaruhi Permintaan Beras di Kabupaten Kudus Jawa Tengah. SPS UNDIP.

Mankiw, G. N., 2000. Buku Pengantar Ekonomi Mikro. Jakarta: Erlangga.

Mankiw, N. G., 2000. Teori Makro Ekonomi. Edisi Ke Empat penyunt. Jakarta: Erlangga.

Martha, R. \&., www.katadata.co.id/berita/2018/02/09/ sedan-tak-selalu-mewah-ppnbm-untuk-mobildisarankan-berdasarkan-harga. [Diakses september 2018]

Moekijat, 2000. Kamus Istilah Ekonomi. Bandung: Mandar Maju, Munawir.

Porter, M., 1986. www.kompasiana.com.[Diakses juni 2015].

Pracoyo, Antyo, \& Pracoyo, T.K,. 2006. Aspek Dasar Ekonomi Mikro. Jakarta: PT Grasindo.

Rusdi, M. D. \& Suparta, M., 2016. Analisis FaktorFaktor Yang Mempengaruhi Permintaan Daging Sapi si Kota Surabaya. Jurnal Ekonomi dan Bisnis, 1(2), 283-300

Sistaningrum, E., 2002. Manajemen Penjualan Produk. Yogyakarta: Kanisius.

Sitorus, S. A., Hasyim, H. \& Jufri, M., 2015. FaktorFaktor Yang Mempengaruhi Permintaan Telur Ayam Ras di Pasar Petisah Medan Tahun 20102014. Journal Of Agriculture and Agribusiness Socioeconomics, 4(10).
Sugianto, D., t.thn. www.finance.detik.com/industri/d3818238/penjualan-mobil-sedan-sepanjang2017-paling-anjlok-ini-penyebabnya/. [Online] [Diakses selasa januari 2018].

Sugiyono, 2014. Metode Penelitian Pendidikan Pendekatan Kuantitatif, Kualitatif, dan R\&D. Bandung: Alfabeta.

Sukirno, S., 2000. Makro Ekonomi Modern. Jakarta: PT Raja Grafindo Perkasa.

Sukirno, S., 2010. Teori Pengantar Makroekonomi. Jakarta: PT Raja Grasindo Persada.

Swastha, B. \& I., 2005. Asas-asas Marketing. Yogyakarta: Liberty.

Undang-Undang Nomor 42 Tahun 2009 Nomor 5 Tentang Penjualan Atas Barang Mewah

Widarjono, A., 2009. Ekonometrika Pengantar dan Aplikasinya. Edisi Ketiga. Yogyakarta: Ekonisia FE UII.

www.bmw.co.id/en/integration/pricelist/

[Diakses Februari 2019]

www.bps.go.id/staticable/2009/06/15/907/indeksharga-konsumen-dan-inflasi-bulnan-indonesia2005-2019.html. [Diakses Februari 2019].

www.daihatsu.co.id/price-list.

www.gaikindo.or.id/indonesian-automobile-industrydata/.

www.gaikindo.or.id/penjualan-sedan-di-indonesiakritis-angka-terendang-terjadi-pada-2016/. [Diakses 2016].

www.hondaglobal.com/pricelist. www.kbbi.web.id/penjualan.

www.mitsubishiberlian.com/price-list/

www.mobiltoyotaauto2000.com/daftar-harga-toyota/. [Diakses 2017].

www.nissanjkt.com/2013/08/price-list-nissan-agustus2013/ [Diakses Agustus 2013].

www.otosia.com/berita/inilah-harga-resmi-chervolets[in. [Diakses Februari 2013].

www.price.hyundaimobil.co.id/.

www.pricelistsuzuki.com/pricelist-suzuki-2016terbaru/. [Diakses Januari 2016].

www.sbm.binus.ac.id/2017/09/05/sistem-dinamis-i/ [Diakses September 2017].

www.toyotajakarta.com/2014/01/daftar-harga-mobiltoyota-di-jakarta/[Diakses Januari 2014].

www.toyotajakarta.com/price-list-toyota/. [Diakses 2013].

www.tribunnews.com/otomotif/2013/08/27/ini-diadaftar-komplet-kenaikan-harga-mobilmazda/[Diakses selasa 27 agustus 2013]. 